\title{
Ouverture ou fermeture brutale d'une vanne en aval d'une conduite
}

\section{Sudden opening or closing of an outlet valve on a pipeline}

PAR

\author{
T. HAYASHT
}

1).S., HOURSER DU GOUVERNEMENT FIANGALS AUPRÈS DE LA SOGRÉAH,

P'ROFRSEUR J'HYDRAULIOUE A I'UNIVERSITÉ CHLO, TOKYO
WT

\author{
G. RANSFORD
}

INGKNIEUR-DOC'TELII SOGRÉAH, GRENOHILE
Celle étude vise a mettre en évidence l'effel de la schématisation des pertes de charge dans des épures Bergeron par des diaphragmes fictifs, l'exécution des épures de coup de bélier étanl confiée da une machine à calculer électronique. Ce faisant, des solutions exactes a la limite (c'est-à-dire pour des pertes de charge uniformément réparties; ont été trouvées pour des lermetures ou des onvertures rapides en aval de conduites très longues ou très élastiques, où les pertes de charge modifient proforidément les phénomènes transitoires.
The aim of this study is to highlight the effect of replacing distributed head losses in water hammer calculations by fictitions diaphrugms, the actual calculations haning been done on an electronic computer.

Exacl solutions for the limiting case of an infinite number of such diaphragms) have inridentally been found for very long or very elastic lines in which head losses considerably modify the nature of mater-hammer transients. $a=$ vitesse de l'onde de cuup de bélier;

$g=$ accélération de la pesanteur;

$h=$ pression évaluée par rapport au débouché de la conduite;

$h^{*}=$ pression maximale mesurée en amont de la vanne fermée, comptée au-dessus du niveau statique;

$k=\frac{1}{1+\left(a V / g H_{f}\right)}$, la perte de charge totale en forme « réduite »;

$m=$ nombre de troncons comportant des diaphragmes fictifs à chaque bout (voir la fig. 1); velocity of propagation of water-hammer surges in the pipeline;

acceleration of gravity;

pressure above datum 0 at pipe outlet;

maximum pressure rise at pipe outlet above static upstream reservoir pressure;

total friction loss in "canonical form";

number of subdivisions of the pipeline for the purpose of studying friction. The fictitious diaphragms materializing friction forces are located as shown on fig. 1 ; 
(n-1),,$(n+1)$ : diaphragmes voisins (voir la fig. 2); $v=$ vitesse instantanée d'écoulement;

$x=\frac{v}{V} \cdot \frac{1}{\left(1+g \mathrm{H}_{f} / a \mathrm{~V}\right)}=(1-k) v / \mathrm{V}$, la vitesse d'écoulement relative en forme « réduite»; $y=\frac{h}{\mathrm{H}_{f}} \frac{1}{1+\left(a \mathrm{~V} / g H_{f}\right)}=k\left(h / \mathrm{H}_{f}\right)$, la pression $x\left[n_{ \pm}, \tau\right], y\left[n_{ \pm} ; \tau\right]$ : valeurs de $x, y$ au poinl $n_{+}$(ou $\left.n_{-}\right)$au temps $\tau$;

$y_{m}=$ valeur maximale de $y$ en amont de la vanne après une fermeture subite, évaluée pour $m$ tronçons $\left(\mathrm{H}_{\mathrm{A}}=0\right)$;

$y_{\infty}=$ limite extrapolée de $y_{m}$, c'est-à-dire la valeur réelle de cette pression maximale;

$$
\left.y_{s t}=\text { valeur statique de } y \text { (pour } \mathrm{H}_{\mathrm{A}}=0\right) \text {; }
$$

$$
y_{s t}=\frac{1}{1+\left(a V / g H_{f}\right)}=k
$$

$\mathbf{E}=$ erreur relative due au nombre fini de diaphragmes;

$H_{A}=$ verte de charge au droit de la vanne partiellement ouverte en régime permanent, avant une fermeture brusque;

$\mathrm{H}_{\mathrm{H}}=$ contre-pression aval, qui peut être négligée dans les calculs par déplacement du plan de référence;

$\mathrm{H}_{f}=$ perte de charge par frottement, vanne levée, lorsque $v=\mathrm{V}$ partout.

$\mathrm{H}_{4}=\mathrm{H}_{\mathrm{A}}+\mathrm{H}_{3}+\mathrm{H}_{f}$, la charge statique mesuréc par rapport à la vanne;

$\mathrm{L}$ : longueur de la conduite;

$\mathrm{V}$ : vitesse d'écoulement en régime permanent, la vanne étant grande ouverte;

$\alpha, \beta$ : coefficients de réduction de coup de bélier et d'ouverture partielle de la vanne, respectivement : $\beta=\mathrm{H}_{f} / \mathrm{H}_{0}$;

$\rho=a \mathrm{~V} / 2 g \mathrm{H}$;

$\tau=t(\mathrm{~L} / a)$, le lemps en forme sans dimensions. Les indices + et - désignent les côtés amont et aval d'un diaphragme fictif. neighbouring subdivisions; see fig. 2; velocity of flow at any time;

the relative velocity in "canonical" form;

the relative pressure in "canonical" form;

values of $x$ and $y$ at point $n_{+}$(or $n_{-}$) at time $\tau$;

maximum value of $y$ reached at the valve after a sudden shut-down with $m$ pipe subdivisions $\left(\mathrm{H}_{\mathrm{A}}=0\right)$;

extrapolated limit of $y_{m}$, i.e. real value of this maximum corresponding to an infinite subdivision;

static value of $y$ (for $\mathrm{H}_{\Lambda}=0$ ), viz.,

$$
y_{s t}=\frac{1}{1+\left(a V / g H_{f}\right)}=k
$$

relative error due to finite number of diaphragms;

head loss at partly-open valve in stearly flow, prior to sudden closure;

tailwater pressure. Without loss of generality can be equated to zero in the calculations;

head loss by friction under steady flow conditions $(v=V)$;

$\mathrm{H}_{\mathrm{A}}+\mathrm{H}_{\mathrm{B}}+\mathrm{H}_{f}$, the reservoir static pressure referred to valve centreline;

length of pipe;

velocity of steady flow out of pipe;

coefficients of pressure rise reduction and of gate opening; $\beta=\mathrm{H}_{f} / \mathrm{H}_{0}$;

«V $/ 2 g \mathrm{H}$

$t /(\mathrm{L} / a)$, time in dimensionless form.

Subscripts + and - refer to upstream and downstream sides of a diaphragn, respectively.

\section{INTRODUCTION}

Il peut paraître assez insolite d'avoir réuni dans la nême publication des études sur le coup de bélier ayant en apparence peu de liens organiques entre elles. Cette juxtaposition résulte de notre désir de tirer toutes les conclusions d'une analyse consacrée primitivement aux seuls effels de l'approximation, habituelle dans l'exécution des épures Bergeron, qui consiste à remplacer les
Briefly outlining the genesis of this study may usefully explain why several, apparently dissimilar aspects of unsteady pipe flow have been grouped together here under one heading.

Originally, it was desired to investigate the extent of errors caused in water-hammer analyses by lumping friction losses at discrete diaphragms. Despite the universality of the prac- 
pertes de charge par frottement réparties sur loute la longueur d'une conduite par des diaphragmes situés à quelques points seulement de celle-ci. Cette pratique est, par la force des choses, universelle; toutefois, personne, jusqu'ici, ne semble avoir entrepris un examen détaillé de ses conséquences.

Notre étude de ce problème se présente ainsi : nous avons choisi d'abord une installation aussi simple que possible (une conduite unique alimentée par un réservoir, une vanne à son extrémité aval étant ouverte ou fermée brutalement afin de créer le coup de bélier), dans le but de mettre en évidence au mieux l'effet du rassemblement des pertes de charge aux extrémités d'un certain nombre (de 1 à 15) de tronçons égaux. La subdivision la plus fine, en 15 tronçons, a permis l'extrapolation à la limite «idéale »d'un nombre infini de diaphragmes.

Il a été supposé d'abord que la charge disponible entre l'amont et l'aval est entièrement utilisée pour vaincre les frottements en régime permanent, la vanne étant grande ouverte, sans qu'elle crée, dans ce cas, de pertes de charge. Cependant, les résultats obtenus pour la fermeture brutale sans perte de charge initiale, sous la vanne, peuvent ètre étendus au cas plus général où, la vanne étant partiellement levée par exemple, des pertes de charge existeraient en régime uniforme avant la fermeture brutale.

Nous avons employé des variables réduites dans cet exposé afin de simplifier la présentation des résultats (surtout le choix, de $« y »$ comme ordonnée plutòt que $(h / H)$ permel de ramener les graphiques de pression aux mêmes dimensions). Ceci étant, et ne considérant que le cas simple où, en régime permanent, la vanne aval ne créerait aucune perte de charge (vanne entièrement levée), nous pouvons définir les caractéristiques de l'installation par le seul lacteur : tice, no previous investigation of the point seems to have appeared. Hence a comparison of waterhammer pressures calculated for different subdivisions of the distributed friction losses in a simple case (sudden opening or closing of a valve at the downstream end of a pipe) is of much value. In carrying out the computations on a punched-card machine, it was convenient to consider grouping sectional friction losses at the ends of pipe sections of equal length ranging in

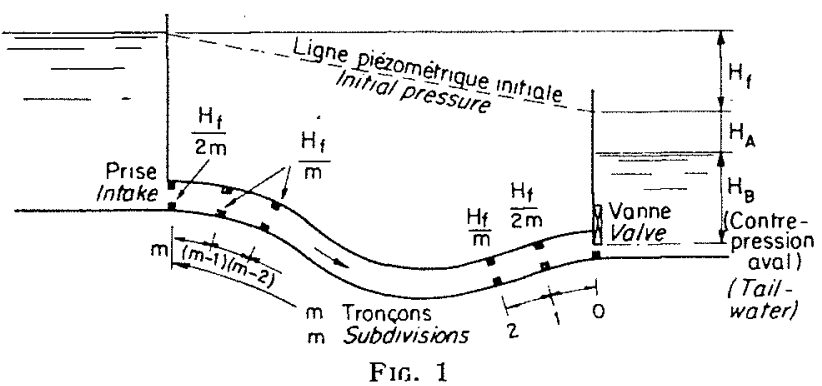

number from 1 up to 15 . The finest of these subdivisions proved adequate for extrapolating the results to the ideal limiting case of infinite subdivision, as the included graphs show.

The entire head difference available between upstream and downstream ends of the pipe was first supposed to be used up in overcoming friction under steady flow conditions; the outlet valve, when raised, caused no head loss. However, the results obtained for the sudden closure of a valve fully open initially can be readily extended to the case of an outlet valve partly raised to start with, pipe friction still being included.

Dimensionless factor's grouping several variables have been used throughout in order to sinıplify the presentation of the results. Presuming that the valve is instantaneously opened or shut to its full extent, i.e., cxcluding the generalization just mentioned in which part openings are considered at the initial instant, the only factor required for defining the physical nature of the set-up under study may be written as :

$$
2 p=\frac{a \mathrm{Y}}{g \mathrm{H}}
$$

Ici, ? désigne le paramètre d'Allievi. La chute disponible $H$ est entièrement absorbée par les frottements en régine uniforme, vanne ouverte. $L a$ vitesse d'écoulement $V$ qui en résulte constitue done une mesure indirecte de la rugosité de la conduite.

Les résultats les plus inattendus ont été obtenus pour les valeurs les plus faibles de $\%$, soit pour $2 \wp=0,1$ à 0,4 environ, s'agissant de la limite «extrapolée » (nombre infini de diaphragmes). C'est dans ces conditions aussi, vers
Here, is of course Allievi's parameter. The head available, $H$, is completely accounted for in overcoming friction in the steady state with the valve fully open. The resulting velocity, $V$, is then an indirect measure of pipe friction.

Now, speaking of the extrapolated limit curiformly distributed friction), the most unusual results were obtained for the lowest values of $q$, in the region $20=0.1$ to 0.4 in particular. In these cases also, the fewest subdivisions $(m=1 ; 2)$ of the pipe in the calculations led to 
$2 p=1$ surtout, que les approximations les plus grossières $(m=1,2)$ conduisent aux écarts les plus élevés par rapport aux valeurs véritables.

Dans la pratique, on peut rencontrer de telles valeurs du paramètre d'Allievi dans les systèmes d'alimentation en eau où on fait appel à des conduites en matière plastique $[2,3,7,8]$. Notre étude sert à souligner deux avantages déjà connus de ces tuyaux : d'une part, lors d'une nuverture brutale de la vanne aval, les débits s'écoulant dans les. instants qui suivent peuvent dépasser de beaucoup ceux du régime établi, et d'autre part, les pressions les plus élevées résultant d'une fermeture subite sont voisines de 1.: pression statique. Des dispositifs imaginés pour réduire la vitesse de l'onde, « $a »$, par une augmentation de la compressibilité de la conduite [5], visent ce dernier résultat aussi.

\section{HISTORIQUE DE LA QUESTION}

Si l'on a prêté aux effets des frottements une attention bien moindre dans le cas des régimes transitoires en conduite que dans celui, qui est pourtant analogue, des ondes dans les canaux, c'est que les distances de parcours et les durées de ces phénomènes, compte tenu de l'amplitude des ondes elles-mêmes, sont bien différentes dans ces deux sortes de problèmes. Les frottements n'agissent que lentement, et leur influence sur une onde de translation typique ayant $1 \mathrm{~m}$ d'amplitude au départ et devant parcourir quelque 3 à $4 \mathrm{~km}$, en 10 minutes, est d'une importance capitale et bien supérieure à celle qu'ils peuvent exercer sur une onde de coup de bélier caractérisée, par exemple, par une amplitude de $100 \mathrm{ml}$ et atteignant l'extrémité d'une conduite forcée de $1000 \mathrm{~m}$ en 1 seconde. Cependant, le sujet garde tout son intérêt dans le second cas, comme nous le verrons.

Jusqu'ici, la plupart des analyses théoriques tenant compte des frottements ont porté sur des approximations linéaires $[6,9]$. Dans le traitement par épures que nous devons à Bergeron [1], les frottements ont été introduits dans l'analyse sons la forme de diaphragmes fictifs. Des résultats intéressants ont déjà été obtenus par ce procédlé [4], qui ne change en rien les équations de base. Une autre méthode graphique proposée par Wood [10] amène an contraire à modifier celles-ci.

Dans la pratique, les épures Bergeron sont d'un emploi classique. Il est clair, tontefois, que la précision du calcul dépend du nombre de diaphragmes choisi. D'autre part, les épures de- the largest discrepancies as compared with the exact, extrapolated results, particularly for $2 \circ=1$, or thereabouts.

In practice, low values such as these of the Allievi parameter may be encountered in the case of long plastic pipes for water supply, as already investigated elsewhere $[2,3,7,8]$. Two advantages of such pipes are recalled here: firstly, when very long, elastic pipes are suddenly opened, flows exceeding those pertaining under steady conditions are made available for a certain time, and secondly the reduction of maximum pressures reached after a sudden closure to values neighbouring on static pressure, is confirmed. Devices for reducing the wave velocity, $a$, by an increase in pipeline compressibility [5] also aim at the latter effect, of course.

\section{HISTORICAL BACKGROUND}

Less attention has been paid to the effect of friction on waterhammer than, say, to its effect on the analogous problem of translation wave propagation in open channels. This is no doubt because the distances and times involved, as compared with the magnitude and duration of the exciting cause (initial wave or shock), differ by several orders of magnitude in these two sorts of problem. Friction requires time and distance to become effective, and its influence on, say, a 1-metre high bore-type wave travelling down a typical 3 to 4 kilometer long channel in $10 \mathrm{minu}$ tes is vastly greater than its effect on a 100-metre pressure wave reaching the far end of a 1000 metre penstock in 1 second.

Previous treatments of the subject have been either analytical or graphical. In the analytical treatments, the effect of friction has generally been introduced into the basic equations by assuming it to be linear $[6,9]$. In his graphical treatment, Bergeron [1] did not modify the basic equations, but used the artifice of lumping frictional losses at selected points, where imaginary diaphragms are supposed to be inserted in the pipe studied. Interesting results have already been obtained using this method [4]. Another graphical method recently proposed by Wood $[10]$ is, however, based on a modification of the basic equations.

The graphical treatment of the Angus-Schnyder-Bergeron type is most commonly used for practical purposes. As far as frictional effects are concerned, accuracy depends on the number of points of division at which diaphragms are located. However, the graphical computations rapidly become unmanageable as the number of subdivisions is increased. For this reason, the 
viennent vite inextricables à mesure qu'on subdivise davantage les conduites. Il a donc fallu disposer d'une machine à calculer digitale pour mener à bien une telle étude. Notons que la machine a exécuté les mêmes opérations que celles d'une épure classique.

\section{LES EQUATIONS DE BASE}

Nous résumons succinctement les formules utilisées dans les calculs sur machine. Des variables réduites $(x, y)$ ont été employées, en partie pour accélérer le déroulement des calculs, mais aussi pour la commodité de la représentation graphique des résultats. A remarquer que present study could not be undertaken without a digital computer. The computer programme has been set up to carry out the same computations as in the standard graphical approach.

\section{BASIC EQUATIONS}

It seems useful to resume the basic formulae employed in the machine computations. Dimensionless variables $(x, y)$ chosen as suitable for particularly rapid processing by the machine have been used throughout. One feature of these variables is the $1: 1$ slope of characteristics.

(A): It is convenient to treat the step-by-step equation at an intermediate point ( $n$, say) along the pipe before considering boundary conditions.

(a)
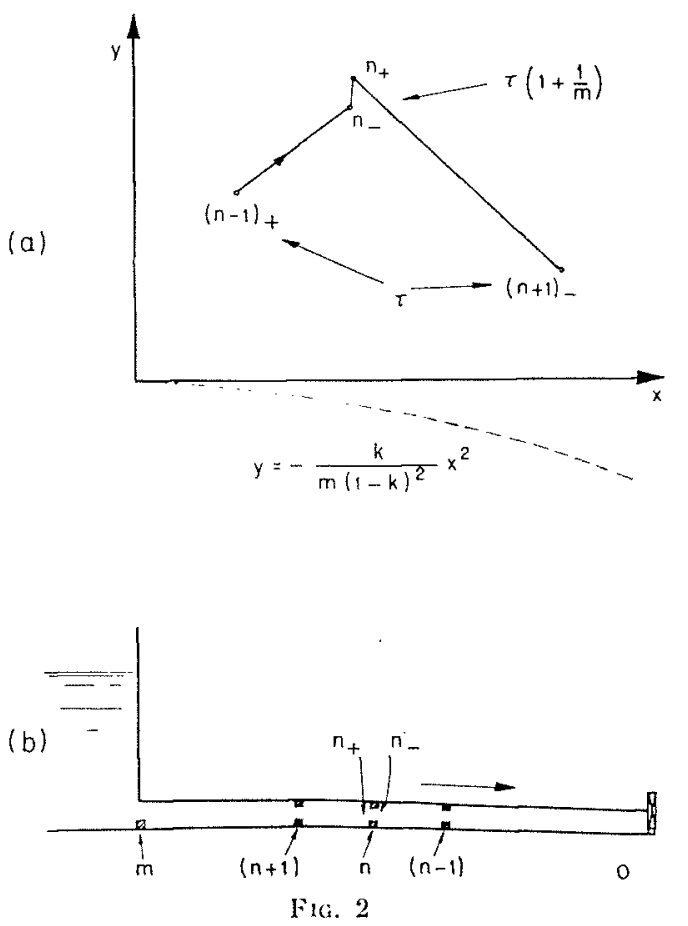

la pente des caractéristiques est de \pm 1 dans ce cas.

A : Considérons d'abord le point courant $(n)$; voir la figure $2(b)$. Nous écrirons les équations donnant à l'instant $\tau[1+(1 / m)]$ le débit, et la pression de part et d'autre du diaphragme, en f'onction des valeurs aux points suivants au temps $\tau$.

Il vient :
Three neighbouring points of division, $(n-1)$, $n$ and $(n+1)$ have to be taken accounl of; see fig. $2(b)$. Moreover, the presence of a fictitious diaphragm at each point leads to a pressure discontinuity, and requires the use of subscript $(+)$ or ( - ) to denote upstream or downstream sides at each point.

According to the standard theory, corresponding to the construction of fig. $2(a)$, values of $x$ and $y$ at point $n$ at time $\tau[1+(1 / m)]$ are given by the following equations:

$$
\begin{aligned}
& y\left[n_{-} ; \tau[1+(1 / m)]\right]=y\left[(n-1)_{+} ; \tau\right]+\left\{x\left[n_{-} ; \tau[1+(1 / m)]\right]-x\left[(n-1)_{+} ; \tau\right]\right\} \\
& \left.\left.y\left[n_{+} ; \tau[1+1 / m)\right]\right]=y\left[(n+1)_{-} ; \tau\right]-\left\{x\left[n_{+} ; \tau[1+1 / m)\right]\right]+x\left[(n+1)_{-} ; \tau\right]\right\}
\end{aligned}
$$


Le débit étant le mème de part et d'autre du where of course, diaphragme, nous avons :

$$
x\left[n_{-} ; \tau\right]=x\left[n_{+} ; \tau\right]
$$

Or, nous savons, d'après la figure $2(a)$ par exemple, que la valeur de $y$ au point $n_{+}$est reliée à celle du point $n_{-}$, du côté aval du diaphragme, par la formule :

$$
y\left[n_{+} ; \tau\right]=y\left[n_{-} ; \tau\right] \pm \frac{k}{m(1-k)^{2}} x^{2}\left[n_{+} ; \tau\right]
$$

Le signe + s'applique lorsque $x>0$.

Par elimination, il vient alors :

The plus sign applies when $x>0$.

Solving these four equations for the values of $x$ and $y$ at time $\tau[1+(1 / m)]$, we obtain for $x$ :

$$
=\mp 1 \pm \sqrt{1 \pm \frac{k}{m(1-k)^{2}}\left\{y\left[(n+1)_{-} ; \tau\right]-y\left[(n-1)_{+} ; \tau\right]+x\left[(n-1)_{+} ; \tau\right]+x\left[(n+1)_{-} ; \tau\right]\right\}}
$$

avec, pour le calcul de $y$ en aval :

The value for $y$ on the downstream side is found from :

$$
y\left[n_{-} ; \tau\left(1+\frac{1}{m}\right)\right]=y\left[(n-1)_{+} ; \tau\right]+x\left[n_{-} ; \tau(1+(1 / m)]-x\left[(n-1)_{+} ; \tau\right] .\right.
$$

Le choix des signes dans la première expression doil être opéré selon que l'expression entre les accolades est positive on négative.

Du côté amont du diaphragme, nous rappelons que :

$$
\begin{aligned}
& x\left[n_{+} ; \tau\left(1+\frac{1}{m}\right)\right]=x\left[n_{-} ; \tau\left(1+\frac{1}{m}\right)\right] \\
& \left.\left.y \mid n_{+} ; \tau\left(1+\frac{1}{m}\right)\right]=y\left[n_{-} ; \tau\left(1+\frac{1}{m}\right)\right] \pm \frac{k}{m(1-k)^{2}} x^{2} \mid n_{-} ; \tau\left(1+\frac{1}{m}\right)\right]
\end{aligned}
$$

The choice of signs in the first of these equations is according to whether the expression in curly brackets $\lessgtr 0$.

On the upstream side of the diaphragms, it is recalled that :
B : A l'extrémité amont de la conduite, au droil de la prise, nous avons les conditions suivantes (en supposant que $\mathrm{H}_{\mathrm{B}}=0$ ) :
(B) : The boundary condition at the intake at the upstream end of the pipe may be written as follows, on the assumption that $\mathrm{H}_{\mathrm{B}}=0$.

$$
\begin{array}{r}
y\left[m_{-} ; \tau\left(1+\frac{1}{m}\right)\right]=k \mp \frac{k}{2 m(1-k)^{2}} x^{2}\left[m_{-} ; \tau\left(1+\frac{1}{m}\right)\right] \\
\left.y\left[m_{-} ; \tau\left(1+\frac{1}{m}\right)\right]=y\left[(m-1)_{+} ; \tau\right]+\left\{x\left[m_{-} ; \tau\left(1+\frac{1}{m}\right)\right]-x[m-1]+\tau\right]\right\}
\end{array}
$$

Le signe à choisir dépend de celui de :

$$
x\left[m_{-} ; \tau[1+(1 / m)]\right] .
$$

II s'ensuit que :

$$
=\mp 1 \pm \sqrt{\frac{\frac{k}{m(1-k)^{2}}}{1 \pm \frac{2 k}{m(1-k)^{2}}}\{k-y[(m-1)+\tau]+x[(m-1)+; \tau]\}}
$$

The choice of signs is according to :

$$
x\left[m_{-} ; \tau[1+(1 / m)]\right] \lessgtr 0 \text {. }
$$

It follows that : 
selon que la grandeur entre les accolades $\lessgtr 0$.

C : Lorsque la vanne est fermée, les conditions suivantes doivent être satisfaites :

$$
\begin{aligned}
& x\left[0_{+} ; \tau\left(1+\frac{1}{m}\right)\right]=0 \\
& y\left[0_{+} ; \tau\left(1+\frac{1}{m}\right)\right]=y\left[1_{-} ; \tau\right]+x\left[1_{-} ; \tau\right]
\end{aligned}
$$

D : Lorsque, par contre, la vanne est grande ouverte, nous avons, dans l'hypothèse que $\mathrm{H}_{B}=0$,

$$
\begin{aligned}
& y\left[0_{+} ; \tau\left(1+\frac{1}{m}\right)\right]=\frac{k}{2 m\left(1-\frac{k}{}\right)^{2}} x^{2}\left[0_{+} ; \tau\left(1+\frac{1}{m}\right)\right] \\
& y\left[0_{+} ; \tau\left(1+\frac{1}{m}\right)\right]=y\left[1_{-} ; \tau\right]-\left\{x\left[0_{+} ; \tau\left(1+\frac{1}{m}\right)\right]-x[1-\tau]\right\}
\end{aligned}
$$

Une relation explicite pour $x$ peut être posée comme suit :

$$
\frac{k}{m(1-k)^{2}} \cdot x\left[0_{+} ; \tau\left(1+\frac{1}{m}\right)\right]=-1+\sqrt{1+\frac{2 k}{m(1-k)^{2}}\{y[1-; \tau]+x[1-\tau]\}}
$$

\section{L.ES CONDITIONS INITIALES}

E : Fermeture brutale intervenant sur un régime établi.

Pour $\mathrm{H}_{\mathrm{A}}=\mathrm{H}_{\mathrm{L}}=0$, les conditions initiales sont les suivantes :

el :

$$
\left.\begin{array}{l}
x\left(n_{ \pm} ; 0_{+}\right)=1-k \\
y\left(n_{-} ; 0_{+}\right)=\frac{2 n-1}{2 m} k \\
y\left(n_{+} ; 0_{+}\right)=\frac{2 n+1}{2 m} k
\end{array}\right\} \text { pour } n>0, \quad \text { for } n>0
$$

(E) : Sudden closure upon steady flow :

For $\mathrm{H}_{\mathrm{A}}=\mathrm{H}_{\mathrm{n}}=0$, the initial conditions are given by :

\section{INITIAL CONDITIONS}

An explicit relation for $x$ may be obtained as follows :

according as to whether the quantity in curly

(C) : The boundary condition at the valve when shut is given by:

(D) : When the valve is fully open, supposing that the back-pressure $H_{B}$ is null, we have :

$$
\text { and } \begin{aligned}
: x\left(0_{+} ; 0_{+}\right) & =0 \\
y\left(0_{+} ; 0_{+}\right) & =\frac{k}{2 m}+(1-k)
\end{aligned}
$$

Ces dernières expressions se déduisent de $\$ \mathrm{C}$.

L'écriture $0_{+}$s'appliquant au temps désigne l'instant immédiatement après la fermeture de la ianne.

F : Ouverture subite.

Pour $\mathrm{H}_{\mathrm{B}}=0$, il vient :

The latter follow dircetly from (C).

The subscript $(+)$ applied to time 0 refers of course to the infinitesimal instant after the valve is operated.

(F) : Sudden opening from rest :

For $\mathrm{H}_{1 \mathrm{~s}}=0$, we have :

et :

$$
\begin{aligned}
& x\left(n_{ \pm} ; 0_{+}\right)=0 ; n>0 \\
& y\left(n_{ \pm} ; 0_{+}\right)=k
\end{aligned} ; n
$$

and :

$$
\begin{gathered}
\frac{k}{m(1-k)^{2}} x\left(0_{+} ; 0_{+}\right)=\cdots 1+\sqrt{1+\frac{2 k^{2}}{m(1-k)^{2}}} \\
y\left(0_{+} ; 0_{+}\right)=\frac{k}{2 m(1-k)^{2}} x^{2}\left(0_{+} ; 0_{+}\right)
\end{gathered}
$$


La dernière condition est une conséquence du $\S \mathrm{D}$.

\section{Remarques :}

G : L'analyse qui précède permet d'aboutir à deux résultats précis, pour le cas où $m$ tendrail vers l'infini :

$1^{\circ}$ L'augmentation brutale de la pression à la vanne lor's d'une fermeture instantanée :

Etant donné que :

$$
y\left(0_{+} ; 0_{+}\right)_{\infty}=1-k
$$

il s'ensuit que :

\section{REMARKS :}

From :

$$
h\left(0_{+} ; 0_{+}\right)_{\infty}=\frac{1-k}{k} \mathrm{H}_{f}=\frac{a \mathrm{~V}}{g}
$$

Cette valeur de la pression sera dépassée toutefois par la suite.

$2^{\circ}$ La vitesse d'écoulement instantanée lors d'une ouverture brutale:

Vu que :

nous trouvons que :

The latter condition is a consequence of (D).

(G) : As $m$ goes to infinity in two of the initial condition relationships, fully accurate limiting values may be obtained for :

(i) The instantaneous pressure rise at the valve when suddenly closed :

This pressure will be exceeded subsequently; however.

(ii) The instantaneous velocity of flow upon sudden opening :

From :

$$
x\left(0_{+} ; 0_{+}\right)_{\infty}=k
$$

it follows that :

$$
v\left(0_{+} ; 0_{+}\right)_{\infty}=\frac{k}{1-k} \mathrm{~V}=\frac{g \mathbf{H}_{f}}{a}
$$

Donc, le rapport $v / \mathrm{V}$ à l'instant inilial dépasse l'unité si $\left(a \mathrm{~V} / g \mathrm{H}_{f}\right)<1$.

C'est un avantage précieux de l'emploi des conduites en matière plastique pour alimenter des usagers éloignés $[7,8]$. Le débil est gonflé pendant les premiers instants suivant l'ouverture d'un robinet. Une limite à la validité de la formule au fur et à mesure que le paramètre d'Allievi diminue, provient toutefois de la hauteur due à la vitesse, ce dont il n'a pas été tenu compte.

\section{GENERALISATIONS}

Les résultats s'appliquent sans, modification au cas où la contrepression $\mathrm{H}_{\mathrm{B}}$ est positive. Dans la pratique, ils ne seront le plus souvent valables qu'à cette condition près, étant donné que nous n'avons pas tenu compte de la cavitation toujours possible. On pourra déterminer à partir de nos résultats si, dans une installation donnée, la cavitation se produira ou non.

On traitera sans difficulté le cas d'une ouverture initiale partielle de la vanne avant une fermeture brutale. On se rappellera que c'est bien $\mathrm{H}_{f}$ qui figure dans les définitions de $x$ et de $y$. Les
Hence, the ratio $u / V$ exceeds 1 when the pipe is opened if $\left(a \mathrm{~V} / g \mathrm{H}_{f}\right)<1$. This is the particular advantage in using plastic pipes in water supply systems to outlying users $[7 ; 8]$. More flow may be obtained in the first instants after opening up than under steady conditions. Neglect of velocity heads in the analysis places a limit on the validity of this result as the Allievi parameter diminishes, however.

\section{GENERALIZATIONS}

Extension to the case in which the outlet backpressure $H_{B}$ is positive is immediate. In many practical applications, results will be valid only if $\mathrm{H}_{B} \neq 0$, seeing that cavitation has not been supposed to occur. In any particular case, it may be readily ascertained, using the present results, whether cavitation will occur or not.

The case in which the outlet valve is partly open prior to being closed is handled analogously; $\mathrm{H}_{f}$ should be considered in the definitions of $x$ and $y$, as been done, and rise in 
surpressions seront évaluées par rapport au niveau de référence fixé par la somme de $H_{A}$ et de $\mathrm{H}_{3}$.

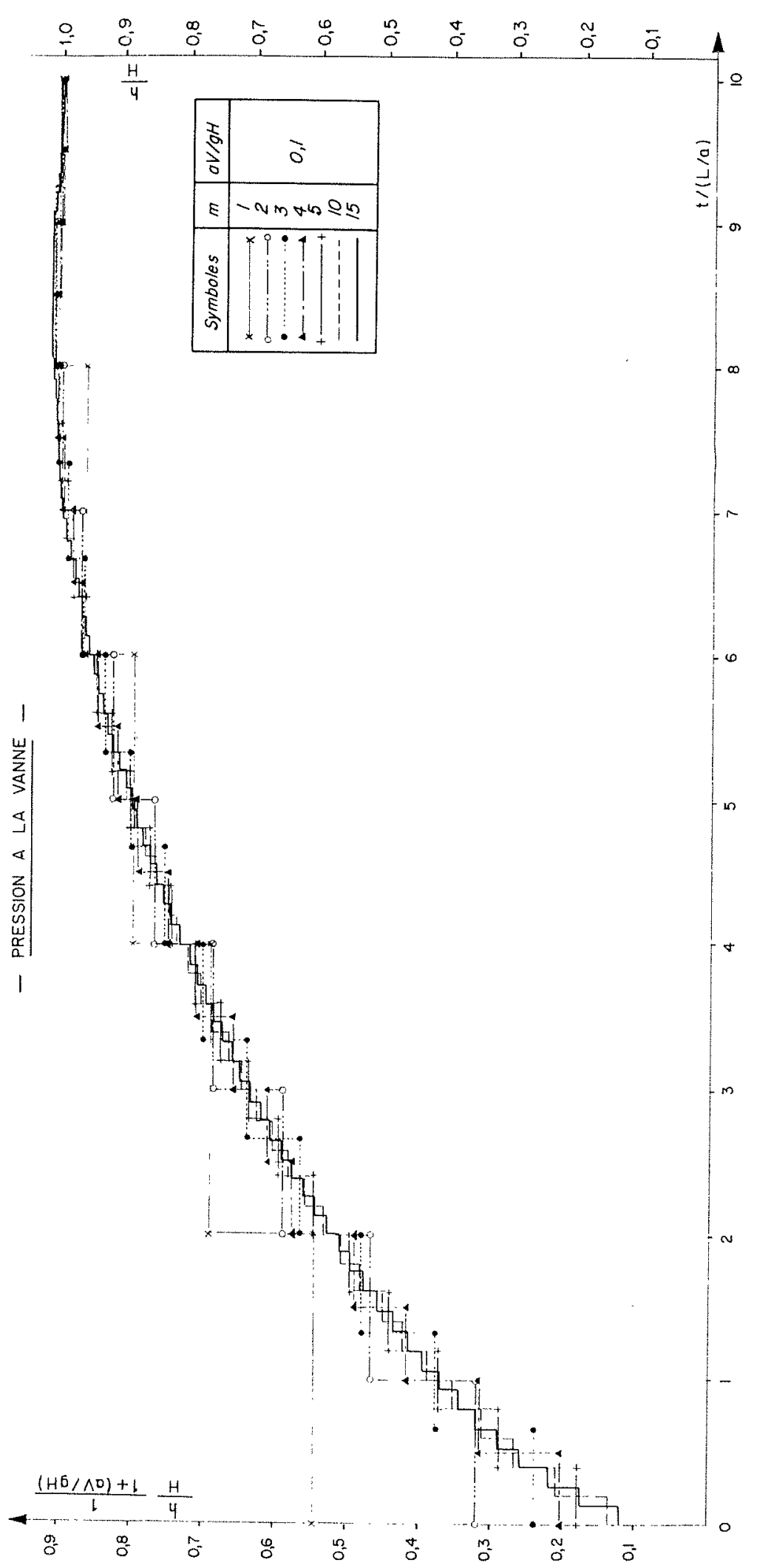

pressure is evaluated with respect to the datum level given by $\left(H_{A}+H_{B}\right)$.

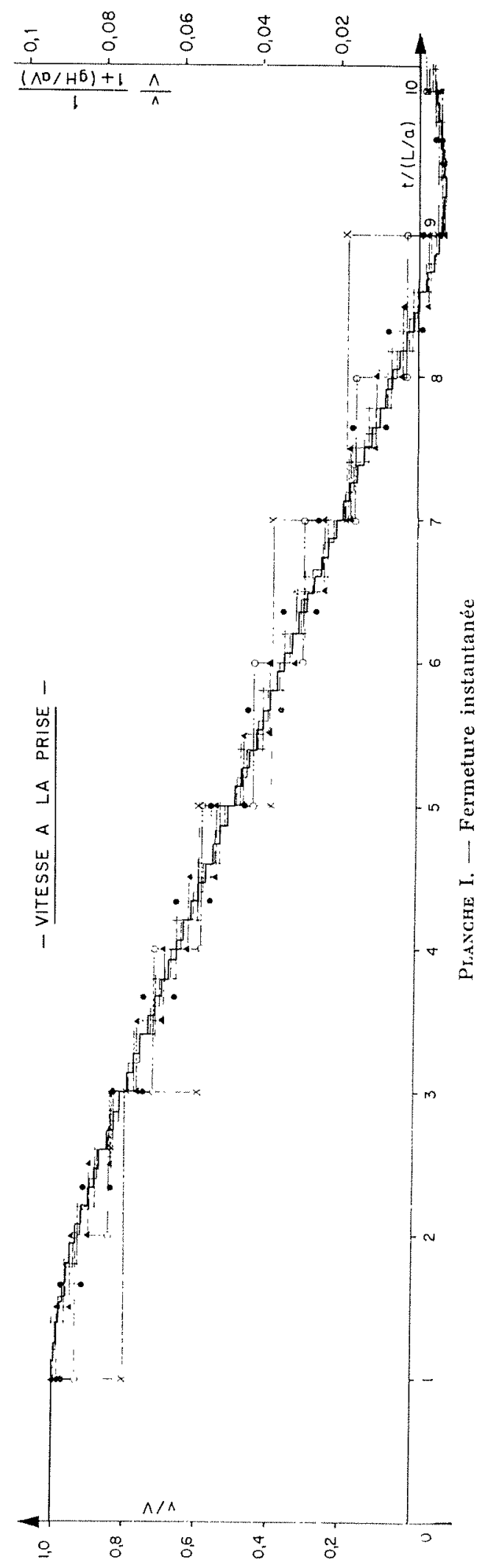



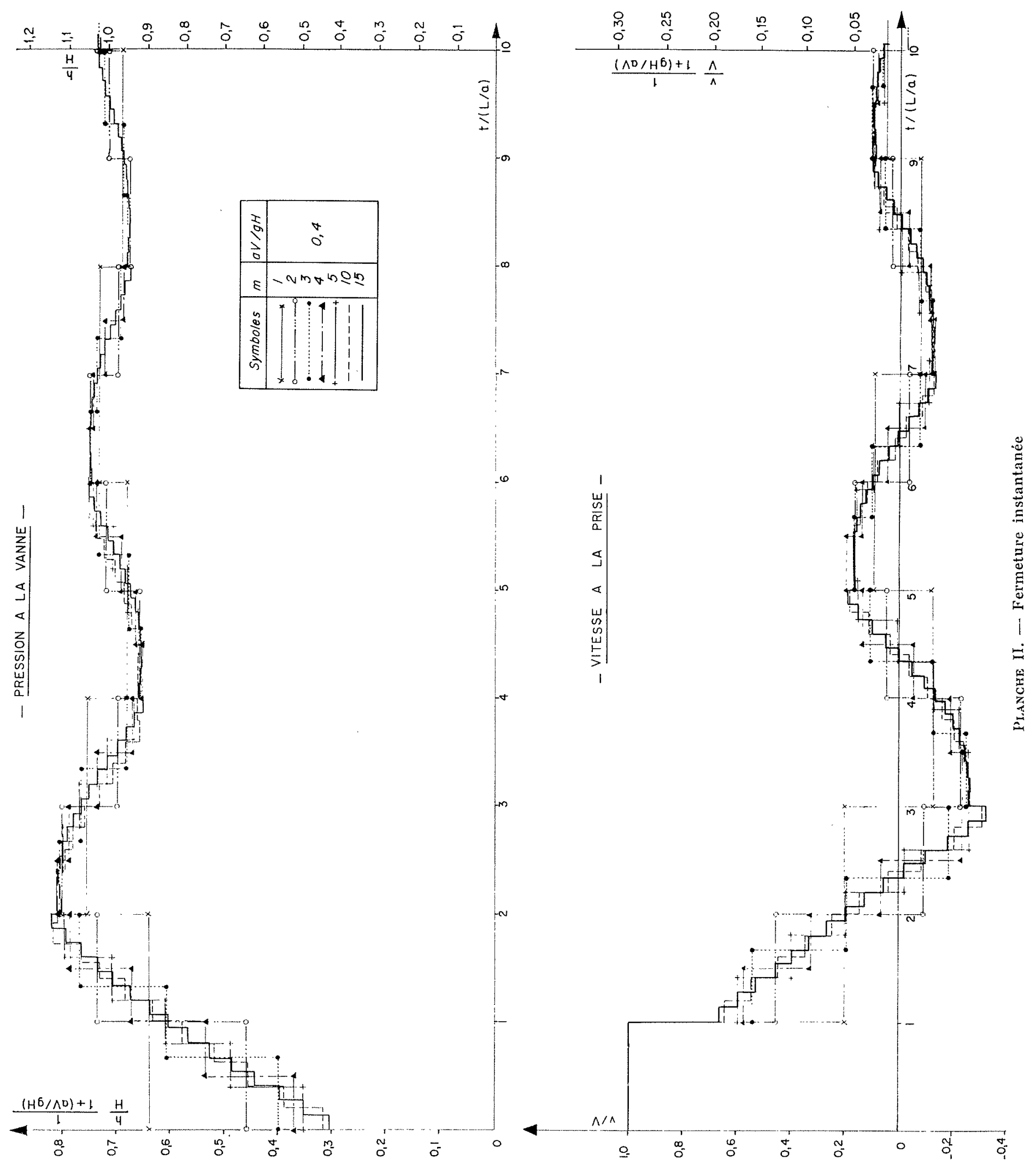

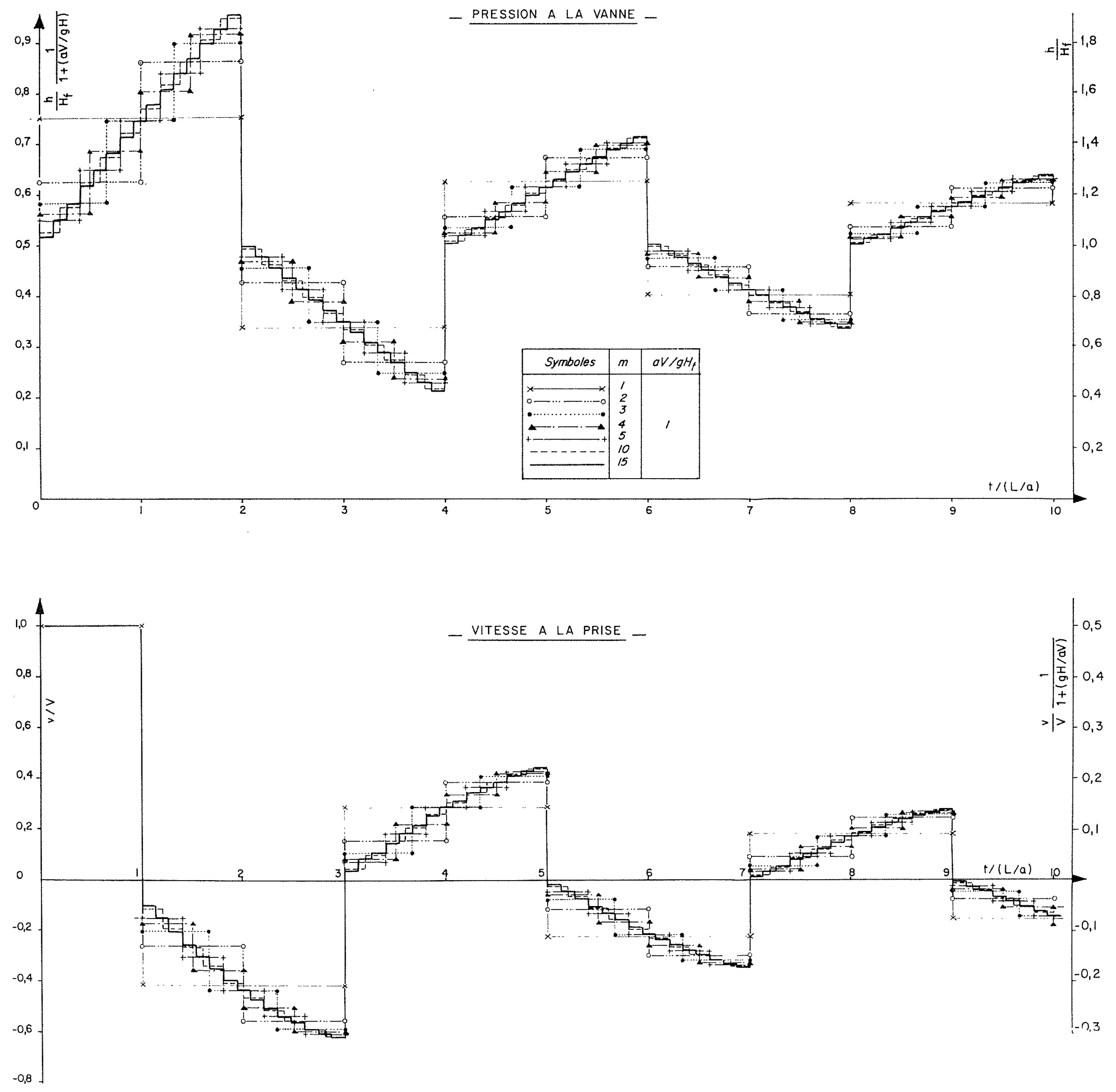

Prasche 1II. - Fermeture instantanec 

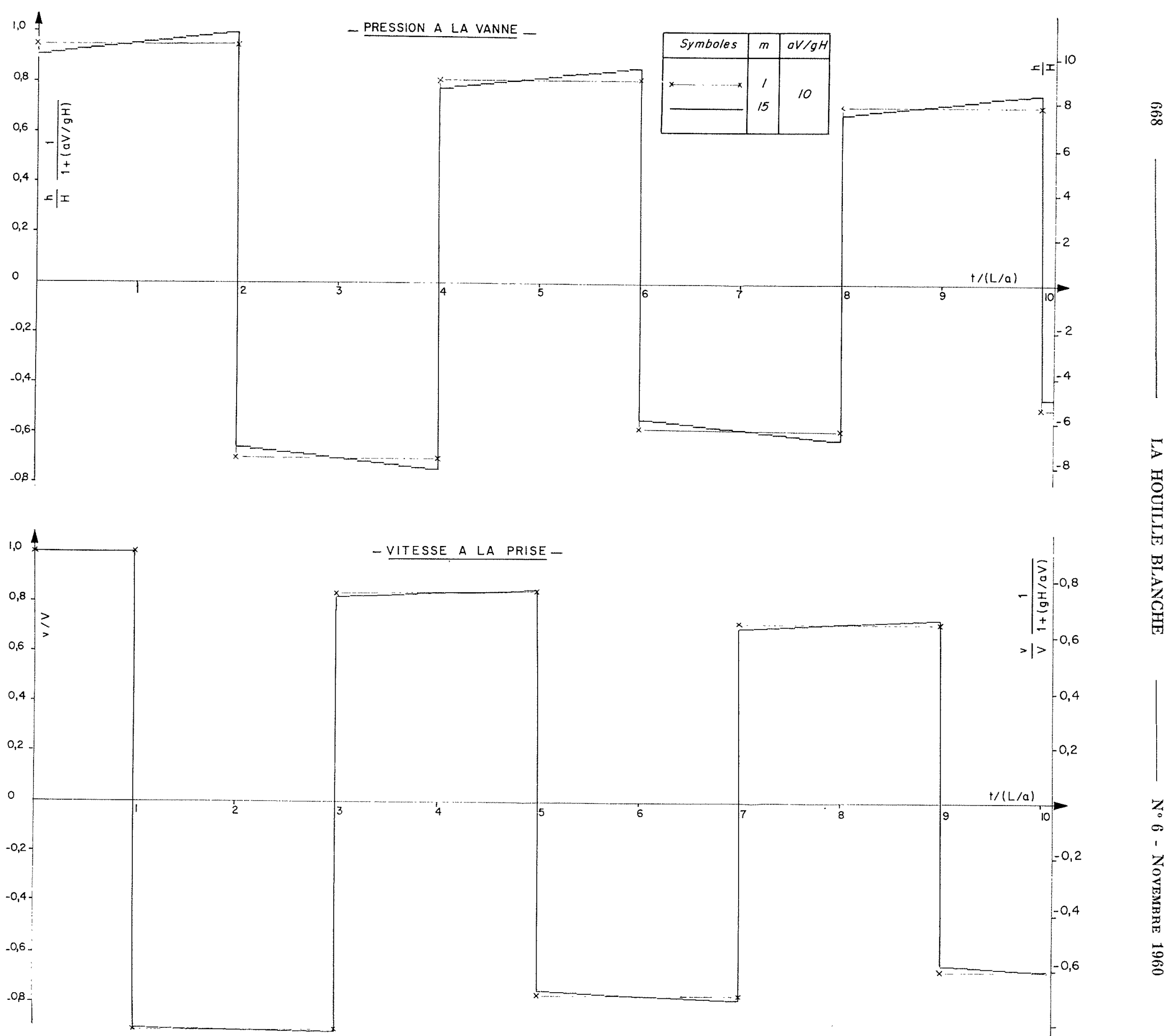


\section{LES RESULTATS}

Les planches I à VI illustrent différents cas de fermelure ou d'ouverture, avec :

$$
a \mathrm{~V} / g \mathrm{H}_{f}=0,1 ; 0,4 ; 1,0 ; 10
$$

Les quatre premières planches ont trait à des fermetures brutales, la partie supérieure de la planche traduisant la variation de pression contre la vanne fermée, et la partie inférieure, la varia-

\section{RESULTS AND CONCLUSIONS}

Plates I to VI show salient results for sudden openings and closures with :

$$
a \mathrm{~V} / g \mathrm{H}_{f}=0.1 ; 0.4 ; 1.0 ; 10
$$

The first four plates represent sudden closures, the upper part of each diagram showing pressures against the closed valve, and the lower part, the variation in the inflow to the pipe after
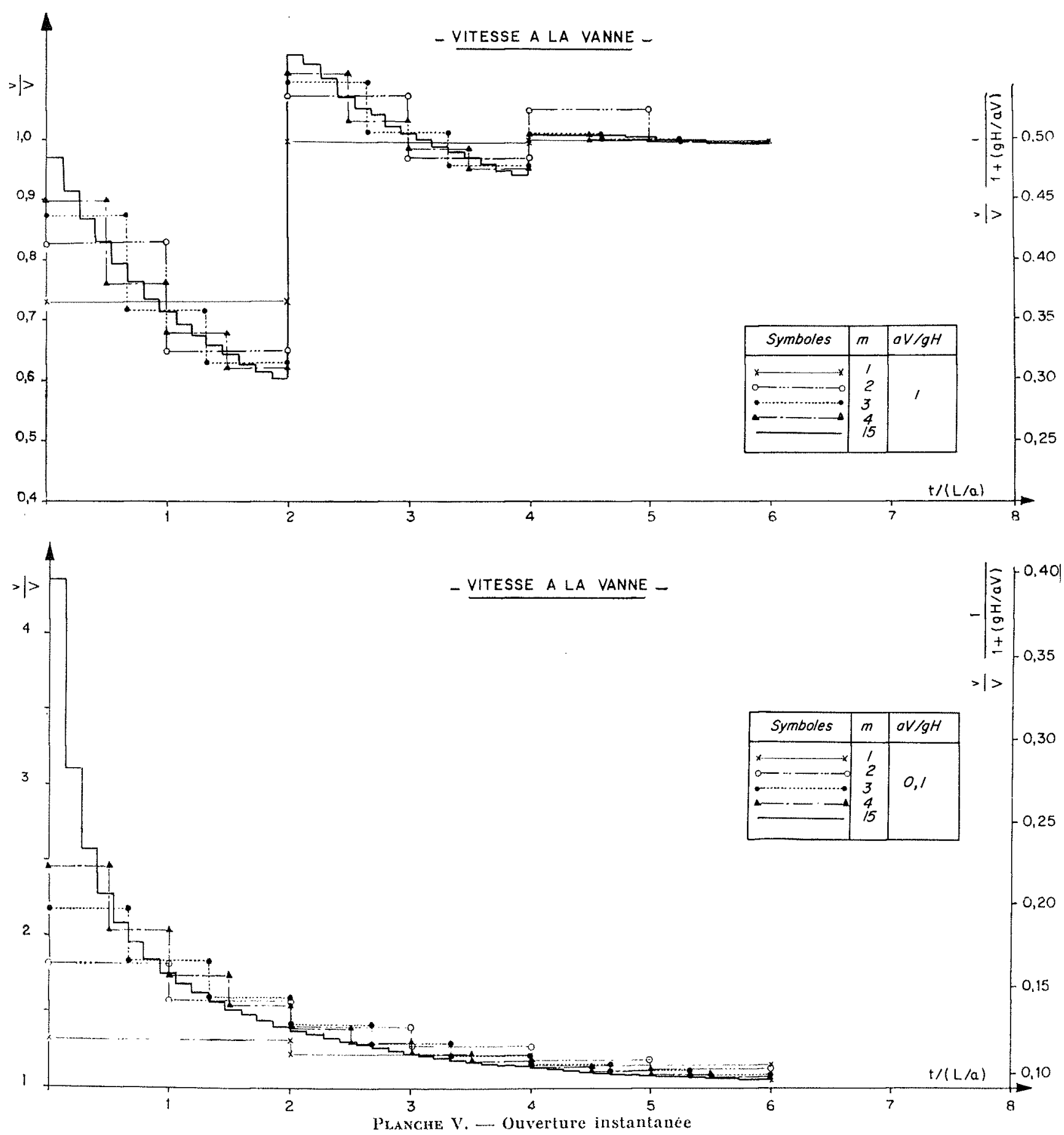

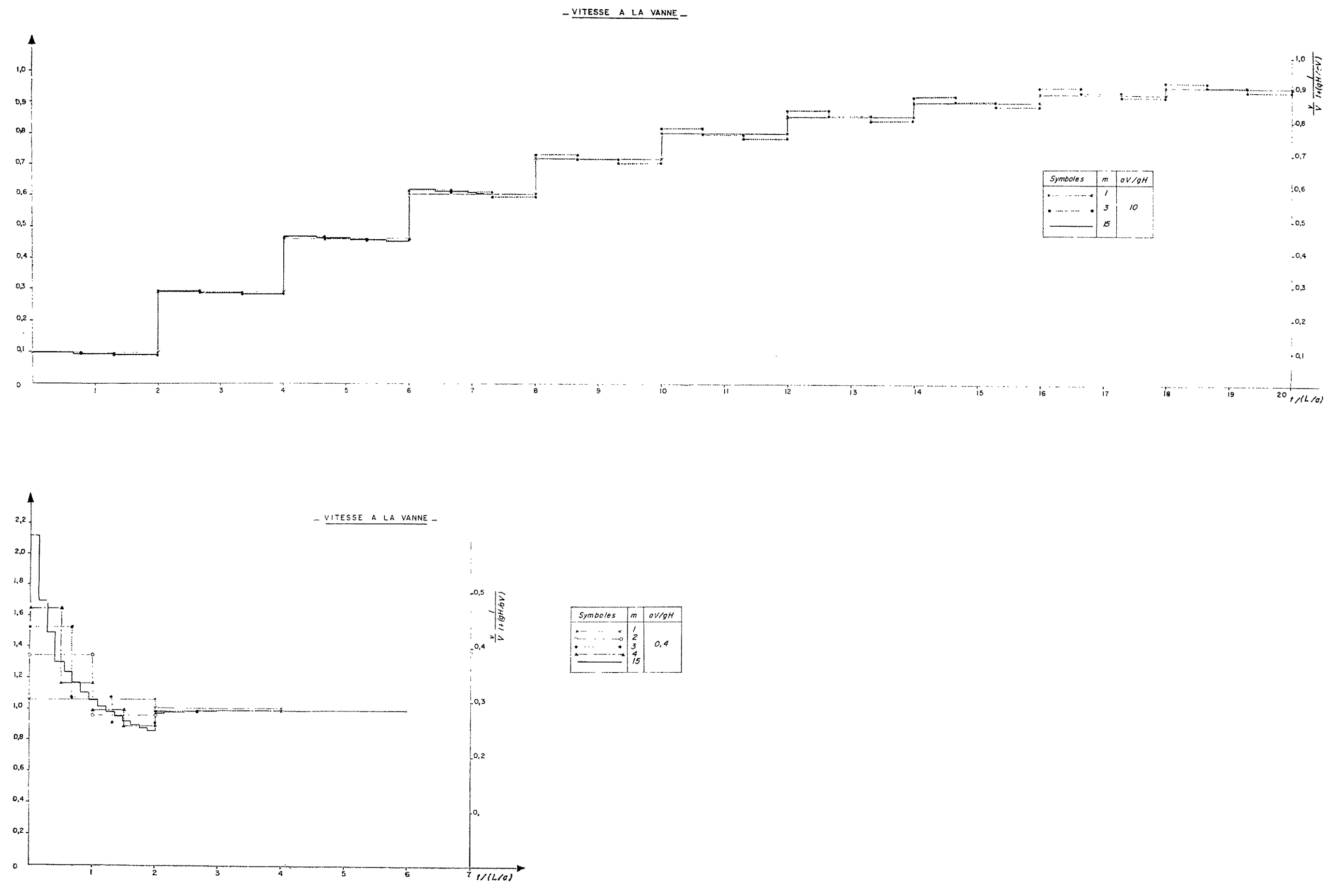

- QUVERTURE INSTANTANEE - 
tion du débit entrant à l'autre extrémité. Les deux planches restantes montrent la variation de la vitesse d'écoulement à l'aval de la conduite après une ouverture. Nous n'avons pu, faute de place, publier les résultats obtenus le long de la conduite.

Les conclusions à tirer de l'étude sont les suivantes :

\section{A) Fermeture brutale :}

Les ondes de pression perdent progressivement leur forme martelée à mesure que le paramètre d'Allievi diminue (pertes de charge élevées ou conduites de plus en plus élastiques). Pour $a \mathrm{~V} / g \mathrm{H}_{f}<0,4$, il ne subsiste plus de périodicité dans la variation de pression constatée à la vanne; de même le débit entrant dans la conduite diminue progressivement, sans à-coups, comme l'indirgue la planche IV.

\section{1" Comparaison de la surpression maximale avec et sans frottements:}

Considérons le cas où $\mathrm{H}_{0}=\mathrm{H}_{f}$, c'est-à-dire où $\mathrm{H}_{\mathrm{A}}=\mathrm{H}_{\mathrm{B}}=\mathbf{0}$ (voir la fig. 1 ).

Sans tenir compte des frottements, la surpression pourrait être évaluée par une formule simple : closure at the other end. The last two plates show the variation in outflow velocity subsequent to a sudden opening of the valve. Results ware also obtained down the length of the pipe, but space precludes their publication here.

The following conclusions may be drawn from an inspection of these results:

\section{(A) SUDdEN GLOSURE :}

The pressure surges progressively lose their square-wave character as the factor $a \mathrm{~V} / g \mathrm{H}_{f}$ is reduced (big friction losses or increasingly elastic pipes). For values of $a \mathrm{~V} / g \mathrm{H}_{f}$ less than 0.4 , the "ups and downs" of pressure which characterize water hammer are ironed out; the inflow of water into the pipe gradually lessens and the maximum pressure is also reached gradually (see the aperiodic curves on Plate IV).

\section{1 : Comparison of the maximum pressure rise with and without friction:}

Consider the case in which $\mathrm{H}_{0}=\mathrm{H}_{f}$, i.e. $\mathrm{H}_{\mathrm{A}}=\mathrm{H}_{\mathrm{B}}=0$. (see Fig. 1).

In simple calculations in which friction is not accounted for, a formula such as :

$$
h_{\max }^{*}=\frac{a \mathrm{~V}}{g}
$$

En fait, la surpression maximale est donnéc par :

would doubtless be used to evaluate the pressure rise. by :

In actual fact the pressure rise is really given

$$
\left.\left.h_{\max f}^{*}=\mathrm{H}_{f}\right\} y_{\infty}\left(1+\frac{a \mathrm{~V}}{g \mathrm{H}_{\mathrm{f}}}\right)-1\right\}
$$

Il est intéressant d'étudier la valeur de :

It is interesting to study the value of :

$$
x=\frac{h_{\text {max } f}^{*}}{h_{\text {max }}^{*}}=\frac{y_{\infty}\left[1+\left(a \mathrm{~V} / g \mathrm{H}_{f}\right)\right]-1}{a \mathrm{~V} / g \mathrm{H}_{f}}
$$

La variation de $\alpha$ en fonction de :

$$
\alpha \mathrm{V} / g \mathrm{H}_{f}=\alpha \mathrm{V} / g \mathrm{H}_{0}
$$

est portée sur le graphique VII (courbe inférieure avec $\beta=1$ ).

Dans le cas général pour lequel $\mathrm{H}_{\mathrm{A}} \neq 0$, c'està-dirc lorsque la vanne en aval est partiellement ouverte avant sa fermelure brutale, le coefficient a variera comme l'indique le sraphique VII en fonction de $\beta$ et $a \mathrm{~V} / g \mathrm{H}_{0}$. Ici $\beta$ désigne le rapport $\left(\mathrm{H}_{f} / \mathrm{H}_{0}\right)$ qui dépend de l'ouverture relative initiale de la vanne.
The variation of $x$ as a function of :

$$
a \mathrm{~V} / g \mathrm{H}_{f}=a \mathrm{~V} / g \mathrm{H}_{0}
$$

is shown on graph VII (lover curve for $\beta=1$ ). In the general case for which $\mathrm{H}_{\mathrm{A}} \neq 0$, i.e., when the outlet valve is partly open only prior to a sudden closure, the coefficient $\alpha$ will vary as shown on graph VII with $\beta$ and $a V / g \mathrm{H}_{0}$; here $\beta$ denotes the ratio $\left(\mathrm{H}_{f} / \mathrm{H}_{0}\right)$, and depends on the initial relative gate opening. 


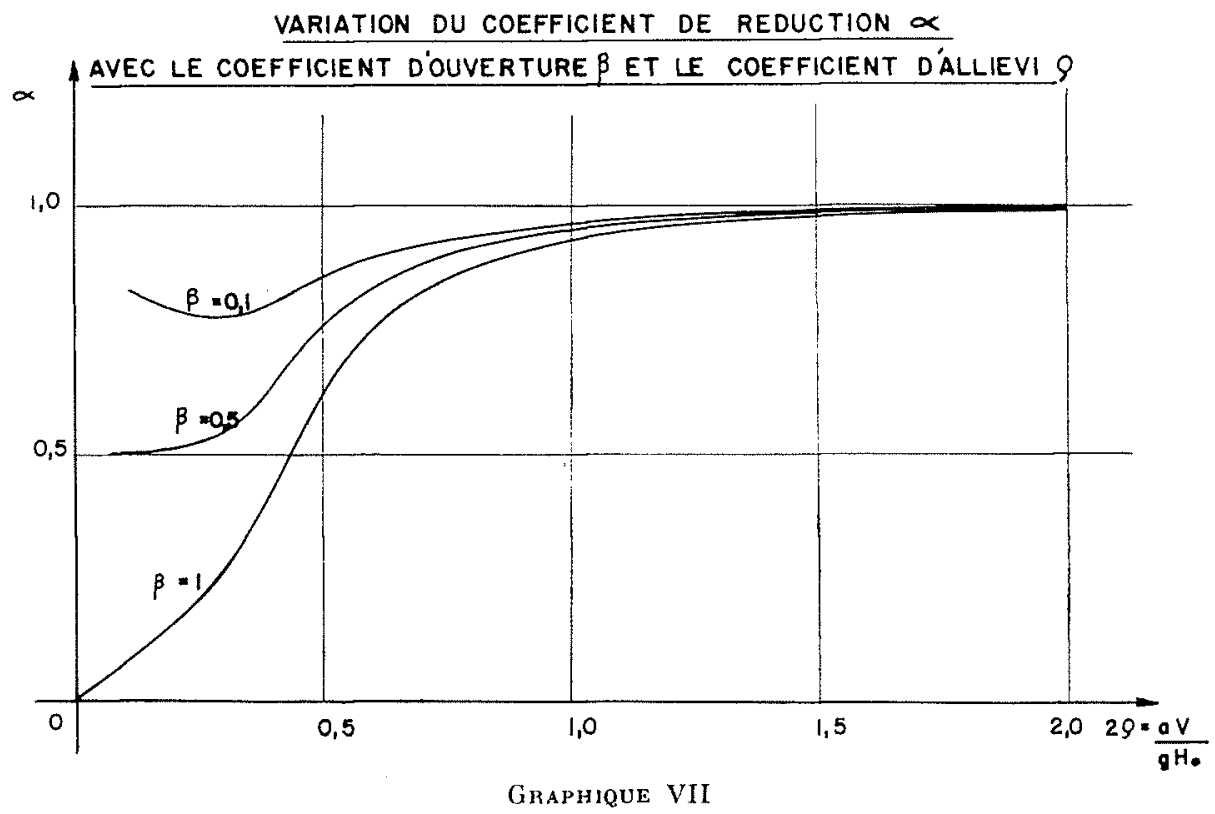

VARIATION DE L'ERREUR AVEC LE NOMBRE DE DIVISIONS $m$

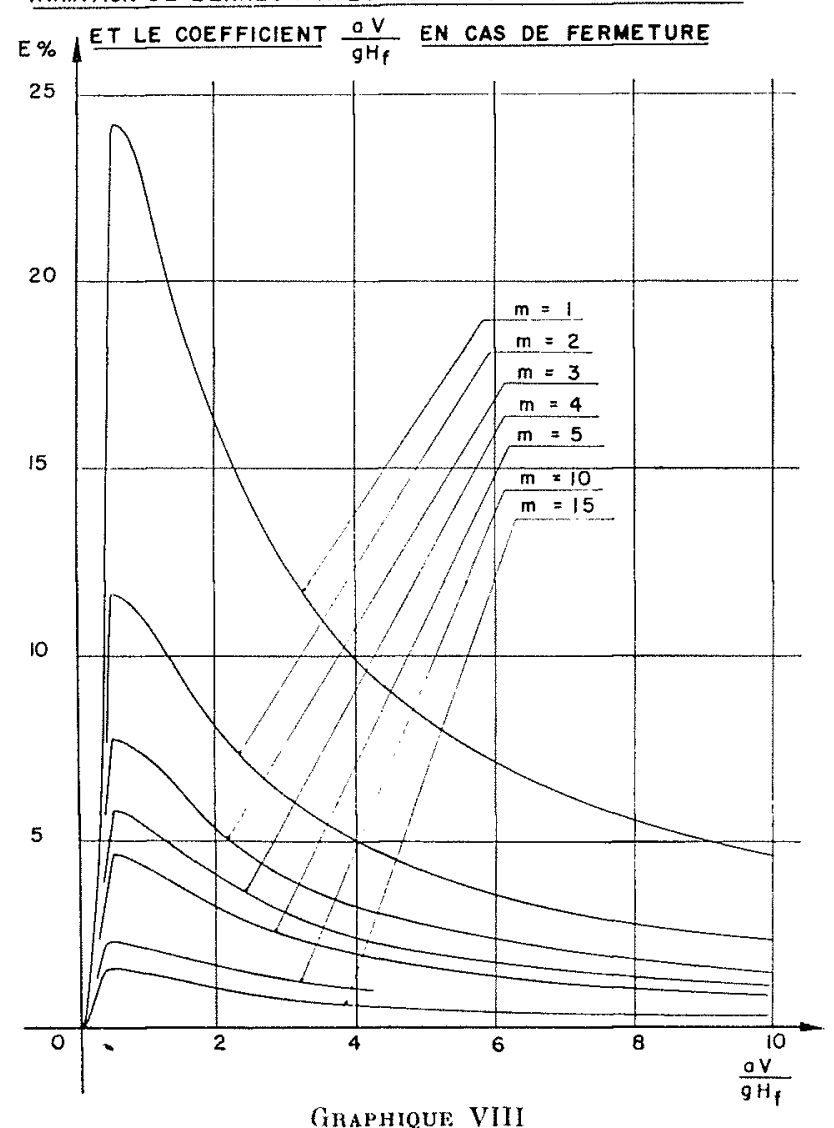

Graphique VIII

2" Errenr due à l'emploi d'un nombre fini de diaphragmes fictifs :

La précision des résultats obtenus dépend du nombre de diaphragmes utilisés, la précision ab-

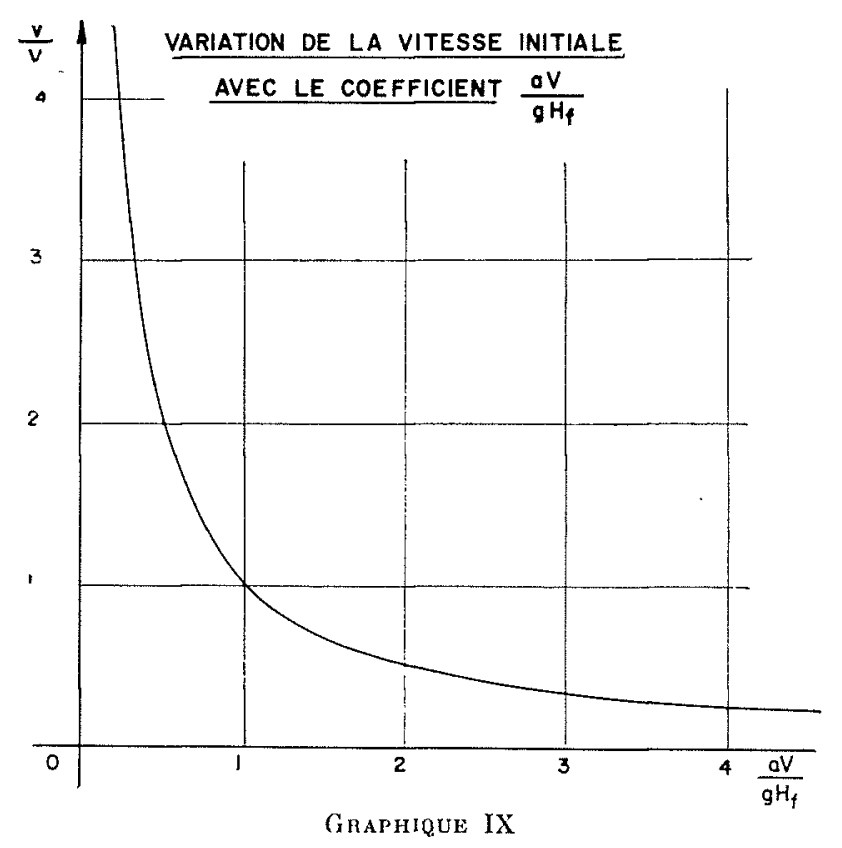

2: Error due to approximating to real head loss by a finite number of diaphragms:

The precision of the results obtained depends on the number of diaphragms used. As $m$ tends 
solue n'étant atteinte que pour $m$ infini. On peut juger de lerreur faite dans des cas concrets d'après la valeur de : to infinity, exact results are attained. One measure of the degree of approximation in any case is found by considering the maximum pressure rise at the valve :

$$
\mathrm{E} \%=\frac{y_{\infty}-y_{m}}{y_{\infty}} \times 100
$$

soit, l'erreur relative (en fonction de $m$ ) sur la pression maximale relevée à la vanne.

Voir le graphique VIII, où $\mathrm{E}$ est porté en fonction de $\mathrm{M}$ et de $a \mathrm{~V} / g \mathrm{H}_{f}$.

\section{B) Ouverture brutale:}

L'existence de vitesses d'écoulement $v$ plus grandes que $V$, la vitesse de régime uniforme, a déjà été démontrée lorsque $a \mathrm{~V} / g \mathrm{H}_{\mathrm{f}}<1$. Voir le graphique IX où l'expression (1) a été portée pour mieux illustrer ce phénomène.
The results are given on graph VIII, as a funclion of $m$ and $a \mathrm{~V} / g \mathrm{H}_{f}$.

\section{(B) Sudden OPENING :}

The existence of initial discharges greater than those corresponding to steady conditions has been proven for $\mathrm{aV} / g \mathrm{H}_{f}<1$. The variation of the instantaneous rate of flow as a function of a $\mathrm{V} / g \mathrm{H}_{f}$ is given on graph $\mathrm{IX}$, according to the relation (1).

\section{BIBLIOGRAPHIE}

I. L. Bentakion : « Du coup de bélier en Hydraulique au coup de foudre en Electricité. $\gg$ Dunod, Paris, 1950.

2. M. Neveux : «Les caualisations d'eau an matières plastiques. 》

Ministère de l'Agriculture, Annales, Mémoires, Notes lechniques, fascicule 76, 1958.

3. M. Othiver : «Vitesses de circulation de l'eau dans les canalisations en matières plastiques. Ministère de l'Agriculture. Etudes et travaux du Centre de Recherches et d'Expérimentation du Génie Rural, no 24, septemble 1954, pp. 1-5.

4. li. Orabona : «Indagine sulla deformazione delle onde di pressione nel moto perturbato in condotte con perdite di carico. 》

Giornale del Genio Civil, 88, 1950, pp. 304-325.

5. G. Remenieras : «Dispositif simple pour réduire la célérité des ondes élastiques dans les conduites en charge. $\gg$

La Honille Blanche, $\mathrm{n}^{\circ} \mathrm{A}, 1952, \mathrm{pp} .172-196$.
6. G. R. Rich : « Water-hammer analysis by the LaplaceMellin transformation. » Trans. A.S.M.E., juillet $195 \%$

7. Stoel-Feuerstein : «Emploj des matériaux plastique. pour tuyaux et appareils pour des distributions d'eau. $\gg$

IV Congrès International des Inistributions d'Ean, 1958, sujet n'2, Rapport général, pp. 71-74.

8. G. Tison : «Le mouvement non permanent succédant à l'ouverture d'une vanne sur une conduite en polyéthystène.»

Communication no 3, BECETEL, 1958, pp, 1-12.

9. F.M. Woon : «Application of Heaviside's operational calculus to the solutions of problems in waterhammer. 》

Trans. A.M.S.E., novembre 1937.

10. F. M. Woon : «Graphical treatment of non-linear friction in water-hammer and surge tank study.» Trans. Engineering Institule of Canada, janvier 1958 , pp. $33-42$. 